\title{
The Impact of Internal Migration on the Spatial Distribution of Population in Germany over the Period 1991-2017*
}

\author{
Nico Stawarz, Nikola Sander
}

\begin{abstract}
In 1885 and 1889 Ravenstein published two seminal papers on the role of migration in changing population distribution. This article analyses the importance of internal migration for shaping the spatial population distribution of Germany in the last three decades. We use a time-series dataset of annual inter-county migration flows from the German population register for the years 1991 to 2017. Population density is used as proxy measure for settlement type as an alternative to the commonly used BBSR typology. Our findings show that around 3 percent of the population moves between counties each year, and that the efficacy of internal migration in redistributing population has declined since the 1990s. Our results are in line with other recent work stating that the re-urbanisation phase, which was prevalent during the 2000s, has ended and sub-urbanisation patterns have become more prominent since 2011. We show that internal migration indeed plays an important role in shaping the distribution of population, especially the movements of young adults and families along the rural-urban continuum. In the 1990s and 2000s, internal migration tended to be more important for shaping regional populations than international migration and natural population change. Notably, this ranking reversed in the last few years and natural population change even became positive for densely settled regions.
\end{abstract}

Keywords: Internal migration - Population redistribution · Population density · Germany · Sub-urbanisation · Urbanisation

\footnotetext{
This article belongs to a special issue on "Internal Migration as a Driver of Regional Population Change in Europe: Updating Ravenstein".
} 


\section{Introduction}

Changes in population size as well as age and sex structure at the regional level have important implications for regional planning and infrastructure provision. In Germany, internal and international migration have been major drivers of regional population change, besides fertility and mortality. A key factor has been the movement between and within East and West Germany after reunification, which has significantly altered the age and sex structure in many eastern regions (Heiland 2004; Kühntopf/Stedtfeld 2012; Sander 2014). Moreover, international migration has an indirect effect on fertility, given that Germany usually exhibits population gains among younger adults of reproductive age (Sobotka 2008).

The ways in which migration shapes regional population change are not a new phenomenon. More than 120 years ago, Ravenstein $(1885,1889)$ published two seminal papers in which he analysed the interrelation of internal and international migration patterns and population change, as well as their spatial outcomes in Europe and North America. The results show that migration was already then a key factor affecting regional population change. Migration in turn was largely driven by economic development and spatial inequalities. In late nineteenth-century Germany, the era of industrialisation unfolded in the context of crop failures and the onset of capitalist agriculture, which led to substantial rural-urban movements towards industrial cities like Duisburg, Essen and Dortmund in the coal-mining region of the Ruhrgebiet.

Since the early works by Ravenstein, migration has become an even more important driving force, especially in the context of low fertility and rising life expectancy (Bujard 2011; Statistisches Bundesamt/Wissenschaftszentrum Berlin für Sozialforschung 2018: 16ff. and 44ff.; Wenau et al. 2019). In Germany and other European countries, research has demonstrated that the impact of internal and international migration on the population distribution and change increased relative to births and deaths since the late 1960s (Birg 1974; Gatzweiler/Schlömer 2008; Rees et al. 2017).

In this paper, we focus on the impact of internal migration on the regional distribution of the population in Germany and how this changed in recent decades (Gatzweiler 1975; Kemper 1985; Sander 2018; Szymańska et al. 2009). We pay special attention to the migration trends among young adults and those aged 30 to 49 years, because these highly mobile age groups tend to have the strongest impact on regional population age and sex structure, thereby also indirectly affecting natural population change. Previous work has shown that the movement of young people from the countryside to the cities entails a rejuvenation of the population in the cities, while more rural localities tend to record an increase in the mean age of the population through migration (Gatzweiler/Schlömer 2008; Mai et al. 2007; Sander 2014). Such movements lead to pronounced regional differences that are mainly discussed within the context of urbanisation, sub-urbanisation and counter-urbanisation, also referred to as the urban development model (Champion 2001; Geyer) Kontuly 1993). For Germany, studies based on population size and the BBSR typology of regions show that the pattern of internal migration has switched from suburbanisation in the 1990s to (re-)urbanisation in the 2000s (BBSR 2018b; Gans 2017; 
Haußmann 2007; Herfert/Osterhage 2012; Milbert/Sturm 2016). However, there are pronounced differences between West and East Germany (e.g. Kontuly et al. 1997). In the East, the sub-urbanisation phase of the 1990s ended earlier than in the West, resulting in net migration for the largest cities becoming positive by the end of the 1990s (Sander 2014; Schlömer 2009). Furthermore, recent studies suggest that the (re-)urbanisation phase has ended in Germany and the pattern switched back to sub-urbanisation in the last few years (Busch 2016; Henger/Oberst 2019). The continued growth in suburban movements has also been found in other western countries (Florida 2017; Frey 2017). Following Ravenstein (1885; 1889), one would argue that these shifts in migration patterns are related to variations in economic development across localities. Indeed, the re-urbanisation in the 2000s seems to have been mainly driven by the rise of jobs in the service sector and the knowledge-based economy that tend to cluster in larger cities (Gans 2017; Geppert/Gornig 2010; Milbert/Sturm 2016). However, the new phase of suburbanisation may be the result of economic counterforces that dampen internal migration into the cities, such as increased rents coupled with housing shortages (BBSR 2018a; Florida 2017; Henger) Oberst 2019).

Against this background, we aim to determine the impact of internal migration on the population distribution in Germany and pay special attention to the changes over time and the shifts between urbanisation and sub-urbanisation over the period 1991 to 2017. This paper contributes to the literature by providing a longer-term perspective on internal migration at the county level within Germany, and by applying the population density approach rather than a settlement typology. Our data comprises a time-series dataset of annual inter-county migration flows for the years 1991 to 2017 based on data of the Federal Statistical Office of Germany and the Statistical Offices of the Länder, which was compiled and adjusted for boundary changes by the Federal Institute for Research on Building, Urban Affairs and Spatial Development (BBSR). To avoid the inaccuracies of existing settlement typologies, we analyse the impact of internal migration on the population distribution using the population density approach proposed by Rees and Kupiszewski (1999; see also Rees et al. 2017). This allows us to capture the full range of the spatial distribution of population across the rural-urban continuum.

The following section lays out the theoretical considerations and the third section outlines the data and methods. We then present the empirical results and conclude the paper with a summary and discussion of the main results.

\section{Theoretical Assumptions}

Following Ravenstein (1885; 1889), we can think of two regularities - or "laws" - of migration that form the point of departure for this paper. First, economic reasons are an important factor for persons to move to economically wealthy regions. Second, cities gain population through migration, while areas that are more rural lose population within the trend towards urbanisation. These two regularities feed into a key question that concerns population researchers and that is the focus of this pa- 
per: How do internal (and international) migration flows alter the spatial distribution of population across regions within a country?

A key aspect of population redistribution is the association between migration and economic development. Earlier work has suggested a relationship in which rising unemployment leads to higher outflows. Economic migration models state that, under the assumption of full access to information and unrestricted mobility, internal migration plays a balancing role and tends to equalise regional disparities (e.g. Harris/Todaro 1970). However, more recent work concludes that migration flows do not reduce regional disparities but rather tend to intensify existing ones (Greenwood 2014, 1975; Krugman 1991). This may at least in part be due to changes in the spatial distribution of jobs and services. However, internal migration from poorer to richer regions may increase the welfare of the total population in a given country. Since occupations in the service sector and knowledge-based economy have become more important for national economies, and those jobs tend to cluster in cities or economically dense localities, an increasing spatial concentration of economic activity can be observed (Florida 2017; Fritsch/Stützer 2007; Gans 2017; Geppert et al. 2008). Correspondingly, studies show a positive correlation between a region's GDP and internal migration, as well as a positive relation between income potentials, business related services, creative industries and population development, while a high unemployment rate tends to dampen internal migration (Birg 1974; Decres$\sin$ 1994; Gans 2017). Moreover, other theories argue that location-specific amenities (e.g. climate, diversity, cultural infrastructure) are important for the decision for a specific location (especially for education-related moves) (e.g. Clark et al. 2002; Florida 2002). In a nutshell, these theories assume that location-specific amenities are a crucial factor for urban development by attracting human capital and jobs or firms. However, Storper and Scott (2009) argue that even if amenities play a greater role, individuals are mainly attracted by the local economy. Therefore, people are more likely to move out of regions with a weak economy regardless of the quality of life in that region (Kawka/Sturm 2006). For Germany, Geppert and Gornig (2010) have shown a rising spatial concentration of jobs in the cities at the expense of jobs in more rural areas. Moreover, the number of employees in the industry sector has decreased in the cities, while those in the service sector and in knowledge-based occupations have increased. In sum, one may conclude that the potential of internal migration to equalise spatial disparities cannot be confirmed empirically. Instead, studies demonstrate that movements between regions tend to intensify existing differences between localities (especially between urban and rural areas). We call this the disparity hypothesis.

\subsection{The urban development model}

Much of the earlier work on migration and regional development was based on the assumption that the process of spatial change is unidirectional, with only urban areas gaining in population through migration. However, we know that the way in which migration redistributes population is not unidirectional, and that periods of concentration may be interrupted by periods of de-concentration. The urban de- 
velopment model (e.g. Geyer/Kontuly 1993) describes the ebbs and flows in how internal migration alters the settlement structure. The model distinguishes between three main patterns: urbanisation, sub-urbanisation and counter-urbanisation (Champion 2001). In simple terms, in the phase of urbanisation, cities exhibit positive rates of net migration and population gains (concentration) due to their positive economic development. If the monocentric structure of the city is overstrained (e.g. infrastructure, limited space, high costs), sub-urbanisation takes place and smaller neighbouring localities show positive net migration rates (intraregional decentralisation), while the net migration rates of the biggest cities decrease. ${ }^{1}$ In the final stage, counter-urbanisation prevails and populations in the lowest density areas increase while the largest cities lose population due to internal migration. This cycle in the development of the settlement structure is observed in several countries, and also in West Germany (Champion 2001). On the contrary, East Germany (the former GDR, where moving patterns where largely shaped by the central planning of housing) experienced urbanisation tendencies from the 1950s until the 1980s, followed by a strong sub-urbanisation period in the 1990s (Mai/Michee/ 2008; Sander 2018).

The urban development model by Geyer and Kontuly (1993) suggests that after a cycle is completed a new one takes place. In line with this assumption, Germany has shown a new phase of urbanisation since the late 1990s (Buzar et al. 2007; Gans 2017; Haußmann 2007; Herfert/Osterhage 2012; Milbert/Sturm 2016). The key driving forces behind the urban revival are a rising number of jobs in the cities (e.g. knowledge based economy), an increased quality of life (gentrification, more cultural opportunities and better infrastructures), an increased number of students, and the general demographic change (e.g. more single households and dual-earner households) as well as a new appreciation of city life (Buzar et al. 2007; Gans 2017; Green 2018; Siedentop 2008). However, more recent studies show that this urban revival has come to an end, and that the pattern has switched back to sub-urbanisation, mainly due to soaring rents and a growing housing shortage in the cities (Busch 2016; Florida 2017; Henger/Oberst 2019).

In sum, from the urban development model we can draw two main conclusions: First, areas with lower population density also benefit in specific phases from internal migration and not just those with the highest density. We call this the differential spatial development hypothesis. Second, the disparity hypothesis must be revised in that internal migration reduces spatial disparities between neighbouring regions and leads to a better infrastructure between those (Geyer/Kontuly 1993). Moreover, those regions with the lowest population density located far away from the largest cities as well as those regions with a weak economic structure tend to lose population through migration (Milbert/Sturm 2016).

1 Already during the urbanisation phase, smaller cities in the hinterland show increasing net migration rates because individuals with high educational level and income want to improve their quality of life and thus move into more rural areas. 


\subsection{Migration decision and age-specific internal migration flows}

The forces discussed in the previous section operate on the macro level. However, we know that the way in which migration alters the spatial distribution of population is ultimately shaped by the actions of individuals (Esser 1996). In simple terms, internal migration flows are the result of individual decisions to move or not to move in search of utility maximisation (e.g. Borjas et al. 1992; Burda/Hunt 2001; Kratz/ Brüder/ 2013). Hence, persons with high levels of education tend to migrate to regions with better labour market conditions or a higher income potential to maximise the returns on their educational investment (Becker 1975). But, as Kecskes (1994) argues, the decision to migrate is typically more complex and requires that individuals need to experience a desire for change or are dissatisfied with their current situation (see also Adam et al. 2008; Rossi 1980; Schulz 2009). Therefore, in a simple migration model, there is a trigger, which causes that individuals search for alternatives to alter the dissatisfying situation (Mulder/Hooimeijer 1999). If relocation is a potential alternative, the individuals subjectively evaluate different destinations based on the search radius, the cost for living space, infrastructures, job market, expected income, and their constraints (e.g. available income) (Lee 1966). This process may lead to the decision to migrate. From this point of view, individuals may relocate to another region after becoming unemployed if there is no possibility to find a new job in the region of current residence. Further complicating the decision-making process, migration is not an isolated decision of an individual but a group decision (e.g. in families), in which the preferences of each single individual are to be considered (Mincer 1978; Stark/Bloom 1985).

From a life course perspective (e.g. Elder 1978; Mayer 2004; Mulder/Hooimeijer 1999), the preferences for a specific living environment as well as the opportunities and costs of relocation for individuals (or couples and families) change across the life course (e.g. birth of a child, becoming unemployed) (Huinink 2005; Kemper 1985; Lersch 2014; Mulder 1993). Therefore, research on internal migration has identified typical age-specific migration patterns (age-specific internal migration hypothesis), which are prevalent in a large number of countries, and can be explained by the underlying migration decisions (Bernard et al. 2014; Dittrich-Wesbuer et al. 2008; Milbert/Sturm 2016; Plane/Jurjevich 2009; Rossi 1980). Young adults aged 18 to 29 have the highest propensity to migrate and tend to move towards urban areas for vocational training, to study or to establish their economic career. For young families (persons aged 30-49) it is more important to improve the quality and quantity of their living space and environment, and so they relocate to more rural localities in search for detached housing. Older adults with stable occupational careers and older children living with them (ages 50-64) show the lowest spatial mobility rates. Those who do move tend to favour rural destinations with lower living costs and/ or high amenities. Persons aged 65 years and over tend to move to be closer to the family, e.g. because of widowhood, grand parenting or the need for institutional or "private" care (e.g. van Diepen/Mulder 2009). In this paper, we consider the life course perspective by studying the impact of age-specific migration patterns on population redistribution. 


\section{$3 \quad$ Data and Methods}

\subsection{Data}

We use a time-series dataset of annual inter-county migration flows from the Federal Statistical Office of Germany and the Statistical Offices of the Länder for the years 1991 to 2017, which was compiled and adjusted for boundary changes by the Federal Institute for Research on Building, Urban Affairs and Spatial Development (BBSR) (BBSR 2010). Therefore the data provide the annual number of moves between $i$ and $j$ (e.g. from Dresden to Hamburg and vice versa) for all 401 counties (Kreise) over a period of 27 years. Since the patterns of internal migration differed significantly between Germans and foreigners in the years 2015 and 2016 due to high inflows of refugees from the Middle East, we look at each group separately. Moreover, we differentiate between six age groups $(<18,18-24,25-29,30-49,50-64$, and 65 and over). We specify the population at risk of migration in a given county as the mid-year population. By drawing on county-level data for births, deaths, immigration and emigration, we distinguish the impact of internal migration from natural population change (births and deaths) and international migration (immigration minus emigration). We use the unemployment rate, GDP per capita and asking rents (Angebotsmieten) measured at the county level to determine the association between internal migration and other contextual factors. Unfortunately, there is a lack of data on rents at the county level in Germany. We thus use asking rents compiled by the BBSR that are based on the commercial apartment listings from internet databases and newspapers as a proxy (BBSR 2016). The asking rents provide a current picture of the cost of living space because they only capture the prices of newly built flats and of older flats that were re-rented to a new tenant.

\subsection{Methods}

To provide an overall picture of the impact of internal migration in Germany on the population redistribution over the period 1991 to 2017, we use the crude migration intensity (CMI) and the migration effectiveness index (MEI) (Bell et al. 2002; Rees et al. 2017). The $\mathrm{CMI}$ indicates the percentage or level of migration, defined as the ratio of moves $(M)$ to the population at risk $(P)$

$$
C M I=100 M / P
$$

The MEI (first proposed by Shryock/Siege/ 1975) captures the imbalance between internal migration flows and counter-flows, and therefore indicates whether internal migration is an efficient mechanism of population redistribution. The MEI can assume values between 0 and 100, while high values indicate an asymmetry of internal migration flows, which means that some regions gain population and others lose. Low values result from closely balanced internal migration flows that have a comparatively small effect on population redistribution. The MEl is computed as follows: 


$$
M E I=100 \sum_{i}\left|D_{i}-O_{i}\right| / \sum_{i}\left(D_{i}+O_{i}\right)
$$

where $D_{i}$ is the total inflow to zone $i$, and $O_{i}$ is the total outflow from zone $i$. Moreover, we also computed the mean distance moved in each year by using the Euclidian distance between the geometric centres of counties created using ArcGIS. To consider both inter-county and intra-county flows, we use the method proposed by Batty (1976). ${ }^{2}$ It is assumed that areas are circular and that the population is evenly distributed within these (for a further discussion see Stil/well and Thomas 2016). We computed the intra-zonal distance for a specific zone $\left(d_{i j}\right)$ as follows:

$$
\begin{aligned}
& d_{i i}=r_{i} / \sqrt{2} \quad \text { and } \\
& r_{i}=\sqrt{A_{i} / \pi}
\end{aligned}
$$

where $r_{i}$ is the radius of a circle that corresponds to the area $\left(A_{j}\right)$ of zone $i$. To determine the effect of internal migration on the population redistribution in a specific region, we use the net migration rate that shows the percentage of population gains or losses due to internal migration. The net migration rate for region $\mathrm{i}, \mathrm{N}_{\mathrm{i}}$ is computed as follows:

$$
N_{i}=100\left(D_{i}-O_{i}\right) / P_{i}
$$

where $D_{i}$ are the total inflows, $O_{i}$ the total outflows, and $P_{i}$ is the population of zone $i$.

Given that the population is not evenly distributed across counties, we need to take into account the settlement structure. In Germany, the settlement classification of the BBSR is commonly used for this purpose. It distinguishes between largest cities, cities, hinterland and rural areas (Milbert 2015). ${ }^{3}$ However, this classification does not adequately capture the complexity of the settlement system. For example, the city of Flensburg is defined as a rural area, but it is indeed a middle-sized city in a peripheral rural environment with around 85,900 inhabitants, and therefore should be rather classified as urban (BMVI 2018). A further limitation of the BBSR classification is that it lacks cross-national comparability. For these reasons, and because the classification does not capture the full-range of the urban-rural continuum (Amcoff 2006; Bocquier 2005; Buettner 2015), we use the population density as a proxy to distinguish between urban and rural areas. This measure has been suggested by Rees and Kupiszewski (1999), but has thus far not been used to study internal migration in Germany (see also Rees et al. 2017). We calculate the population density

2 However, both the corrected distances moved as well as the uncorrected lead to similar conclusions about the change of the distances moved over time, but differ in their level.

3 We also conducted analyses using the BBSR area classification, which lead to similar results as reported below. 
by dividing the number of inhabitants $\left(P_{i j}\right)$ in given zone $i$ and year $j$ by the area $\left(A_{i}\right)$ measured in $\mathrm{km}^{2}$ and then take the base-10 log of population density. ${ }^{4}$

We use simple but effective linear regression models to determine the association between population density and internal migration (Rees et al. 2017). To estimate the impact for several years, we use random effects (RE) models, which consider autocorrelation over time (Rabe-Hesketh/Skrondal 2012). ${ }^{5}$ We do not consider any covariates because our analyses are mainly of descriptive interest. The slope of the regression line shows how internal migration $(y)$ and population density $(x)$ are related. For example, a positive b-coefficient indicates a positive relation between the net migration rate and the log of population density, which means that more densely populated regions gain more population through internal migration compared to lower densely populated localities. However, given that a linear association may lead to biased results, we also used cubic slopes to model patterns that are more complex.

\section{$4 \quad$ Results}

We first give an overall picture of the impact of internal migration in Germany on the population redistribution over the period 1991 to 2017 . Figure 1 shows the crude migration intensity $(\mathrm{CMI})$, the migration effectiveness index (MEI), and the mean distance moved for the period 1991 to 2017.

The CMI shows that about 3 percent (mean across all years $\bar{x}=3.25$ ) of the population in Germany moves across county boundaries each year (Fig. 1a). The values were relatively stable until 2011 and increased thereafter to almost 4 percent. However, this is largely due to the high immigration numbers recorded in these years, and the systematic redistribution of refugees across municipalities. Compared with other countries such as Finland, Australia or Denmark, the population in Germany is only moderately mobile (Rees et al. 2017). Note that, since the number of spatial units (i.e. the MAUP) affects the CMl, this limits comparisons between countries, and observed differences should be interpreted with care. However, using more advanced measures such as the ACMI proposed by Bell et al. (2015) yields a similar pattern with Germany being a moderately mobile country compared to Finland, Australia or Denmark. The impact of migration is also modest when considering its effectiveness in redistributing population.

The MEl is relatively small across the entire period $(\bar{x}=7.97)$, indicating rather balanced migration flows in Germany. The MEl values decreased over the observed

4 However, the population density measure also has its shortcomings. It is based on the size of regions without considering function, land use and infrastructure. Furthermore, the usual resident population is used without considering daytime populations (i.e. commuting) (Brenner) Schmid 2014; Coombes/Raybold 2001; Parr 2007).

5 Moreover, we also estimated models that consider spatial autocorrelation (Anselin 2009). These models (not reported) yield very similar estimates and lead us to the same conclusions as the models shown here. 
Fig. 1: Crude migration intensity, migration effectiveness index, and distance moved, 1991-2017, for the total population and for Germans only
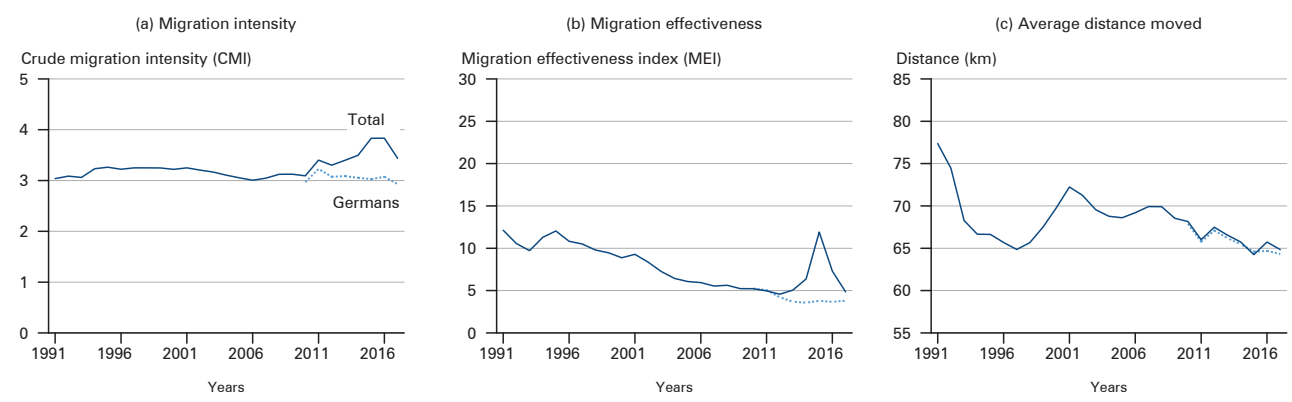

Source: Federal Statistical Office of Germany and the Statistical Offices of the Länder, Spatial Monitoring of the BBSR, own calculations

period, except for the last few years (Fig. 1b). The higher values in the 1990s are the result of the unbalanced migration flows between East and West Germany after reunification, which led to population losses in the eastern part of Germany. The decline of the MEl since 1991 shows that migration flows have become more balanced over time. The peak in the years 2014 to 2016 is - as shown above - a consequence of the high immigration numbers in these years and the distinctive internal migration patterns of newly arrived foreigners. When comparing the effectiveness across countries, Germany shows lower MEI values than Spain, Canada or Russia (Rees et al. 2017), suggesting a modest role of migration in population redistribution within Germany and a relatively stable settlement system.

As the settlement pattern and the high level of development in Germany suggest, the mean migration distance is relatively short. When considering both intraand inter-county flows, the mean distance moved across all years is $68 \mathrm{~km}$. In the early 1990s, the mean distance was higher due to the longer-distance moves from East to West Germany. This is also true for the early 2000s, when East-West migration peaked for a second time. In the late 1990s, the emerging sub-urbanisation trend meant that the distance decreased, given that people moved from cities to neighbouring counties (see Fig. 1c). This also holds for the urbanisation phase in the late 2000s. Overall, we see a constant decline of the distance moved since the early 2000s, thus indicating - as Busch (2016) noted - a prevalence of movements from the cities to closely surrounding counties.

In a next step, we look at population density as a proxy for settlement structure. Figure 2 shows the spatial variation in population density in 2017. The map illustrates that the population density seems to be a good proxy for classifying counties. Cities like Munich, Berlin, Hamburg, and Leipzig are clearly indicated as densely settled areas and rural localities in the north of Bavaria, Mecklenburg-West Pomerania, Schleswig Holstein and Brandenburg show low density values. The densely settled areas in the Ruhr district and the region of Cologne, Bonn and Frankfurt are clearly visible. However, the counties surrounding Berlin have a low density, although the city has spread across county boundaries into Brandenburg. However, this is more 
Fig. 2: Classification of counties using population density in Germany

\section{Logarithmised population density, 2017}

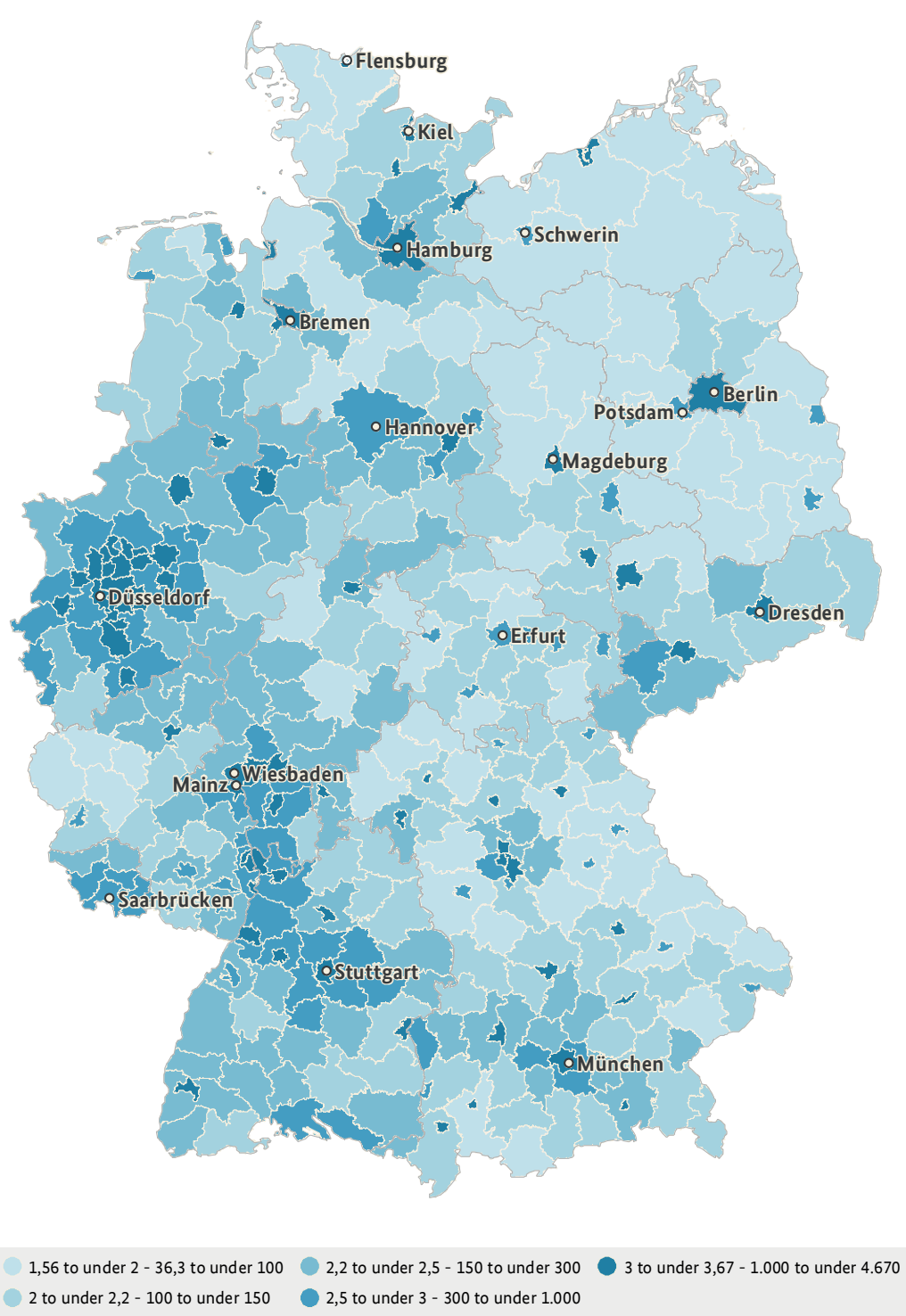

Source: Federal Statistical Office of Germany and the Statistical Offices of the Länder, Spatial Monitoring of the BBSR, own calculations, (c) GeoBasis-DE/BKG (2017) 
a problem of the size and shape of the counties (i.e. the MAUP) rather than a problem of the density measure itself.

Figure 3 shows the distribution of the log of population density in 1991 and 2017 using kernel density estimates. Following the OECD (2007), which defines localities with fewer than $\mathrm{d}=150$ inhabitants $/ \mathrm{km}^{2}(\log (\mathrm{d})=2.18)$ as rural and areas with more than $\mathrm{d}=300$ inhabitants $/ \mathrm{km}^{2}(\log (\mathrm{d})=2.48)$ as urban, we see that the distribution peaks within the rural category. The means of the population density in 1991 and $2017\left(\bar{x}_{\mathrm{d} 1991}=2.43\right.$ and $\left.\bar{x}_{\mathrm{d} 2017}=2.44\right)$ and the kernel estimates show that the distributions are close together. Both, less and higher densely settled areas have become more prevalent in 2017 compared to 1991.

So, how does the density measure compare to the standard settlement classification by the BBSR? In figure 4, we plott the average population density by the BBSR settlement types. Overall, the density measure is in line with the BBSR classification. However, for 32 counties, the density measure differs from the BBSR classification. For example, Flensburg, Bayreuth, and Amberg are classified as rural and Schweinfurt, Bamberg, Eisenach, Frankfurt (Oder) as hinterland. Based on the density measure, these counties are classified as urban areas. ${ }^{6}$

Fig. 3: Smoothed probability distributions of population density for the years 1991 and 2017

Probability distribution (Kernel density)

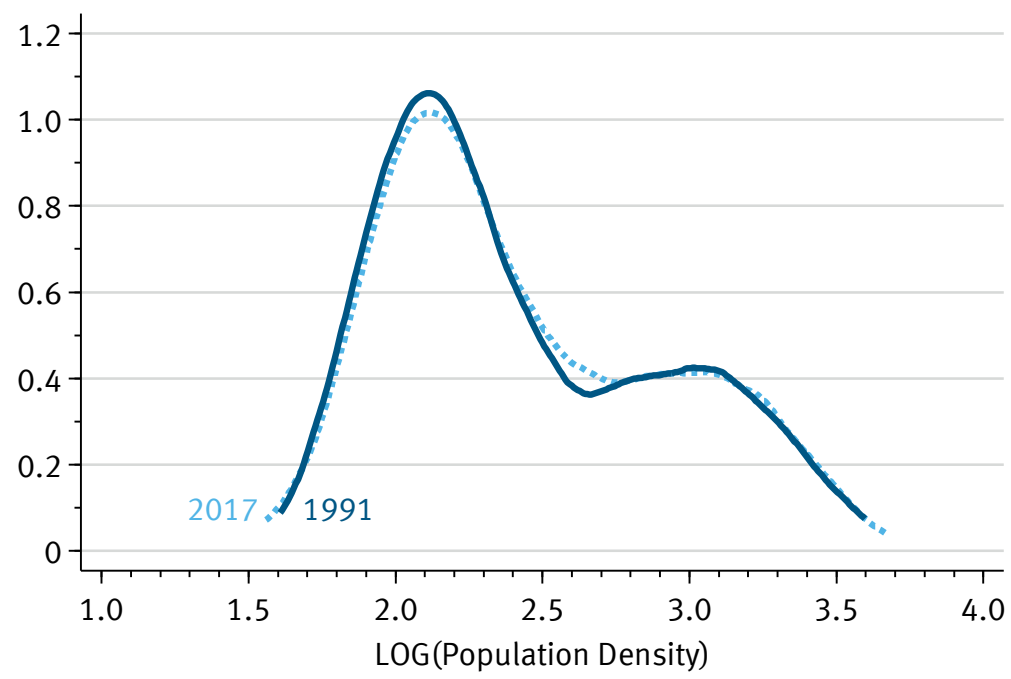

Source: Federal Statistical Office of Germany and the Statistical Offices of the Länder Spatial Monitoring of the BBSR, own calculations, bandwidth 0.29

6 We also conducted some of the analyses presented in the study employing the BBSR typology, which lead to similar conclusions. 
Fig. 4: $\quad$ BBSR typology and population density in 2017

LOG(Population Density)

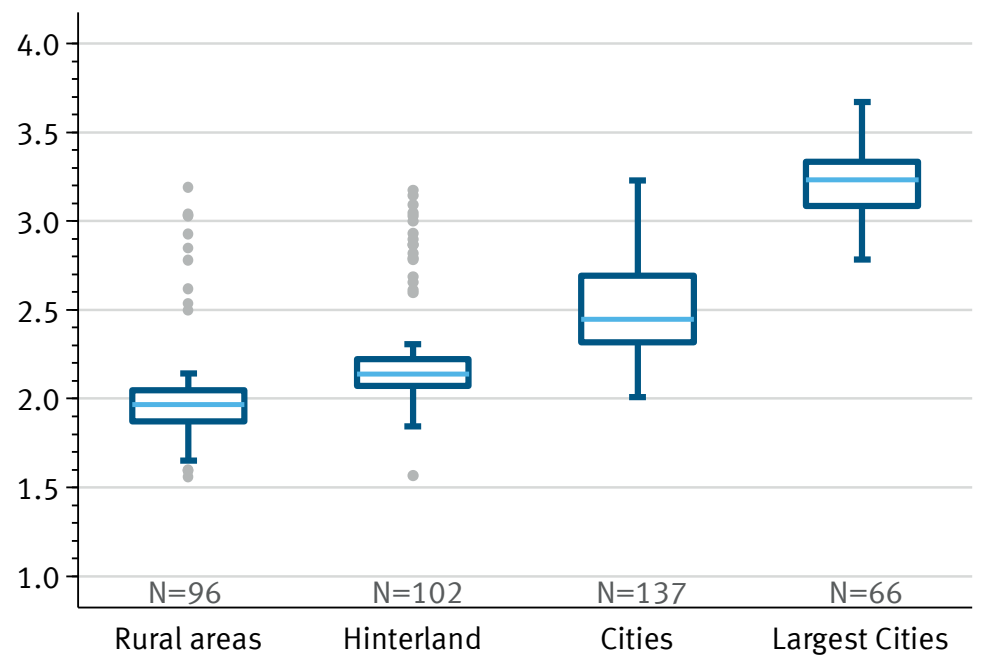

Source: Federal Statistical Office of Germany and the Statistical Offices of the Länder, Spatial Monitoring of the BBSR, own calculations

In a next step, we examine how net internal migration rates relate to population density. We adopt the approach used by Rees et al. (2017) to model the relationship between rates of net migration and the logarithm of population density by estimating linear regression slopes for selected years (see Fig. 5). For 1994 we find a negative relation $(b=-0.74)$ between the net migration rate and population density. The estimates show that on average localities with densities between 1.5 and 2.5 gain population from internal migration while those with higher density lose. The confidence intervals indicate that this relationship does not hold for all regions, suggesting that there is some degree of variation among regions with similar population density. In 1994, populations in more rural areas increased due to internal migration, while populations in urban areas shrank, also referred to as the sub-urbanisation phase of the 1990s in Germany. For 2006, we see a positive relation of population density and internal migration $(b=0.46)$, which is in line with the re-urbanisation phase that prevailed in the 2000s. In 2017, the relationship between net migration rates and population density $(b=-0.18)$ changed again, suggesting the beginning of a new sub-urbanisation phase in that people move to lower density regions.

Figure 6 summarises the shifts between sub-urbanisation and (re-)urbanisation across time. Here, we show the relationship between net migration rates and population density over the period 1991 to 2017 using random effects (RE) models with interaction effects. Note that negative coefficients indicate population gains due to internal migration for lower density regions, while the same is true for higher density regions in the case of positive coefficients. In the early 1990s, we find a weak relationship between population density and internal migration, which may 
Fig. 5: Net internal migration rates by population density (regression slope and 95 percent confidence intervals)

Net internal migration rate (\%)

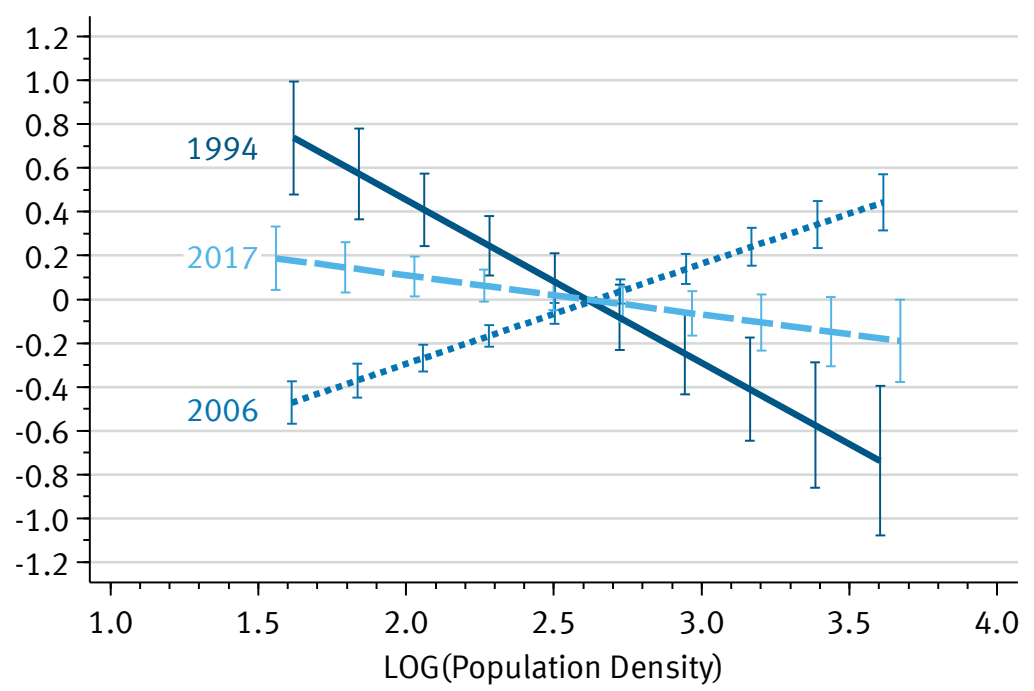

Source: Federal Statistical Office of Germany and the Statistical Offices of the Länder, Spatial Monitoring of the BBSR, own calculations

be due to high volumes of movements from rural areas in the East to cities in West Germany. In the mid- and late 1990s, sub-urbanisation was characterised by population gains in rural areas. In the early 2000 s, the weak relation between net migration and population density indicates that the pattern switched back to urbanisation, with population gains in high density areas in the late 2000s. After 2011, the coefficients decrease showing that the re-urbanisation ended, and since 2014, we find an increasingly negative relation between net migration rates and population density, displaying population gains in lower density regions. The high immigration to Germany between 2014 and 2016 blurs this effect a bit.

To take variations in migration behaviour across the life course into account, we calculate the coefficients for the relationship between net migration rates and (the log of) population density for the period 1991 to 2017 for six age groups also deploying RE models (see Fig. 7). Across the entire period, the relationship is strongest for those aged 18-24 years, followed by those aged 25-29 years. For all other ages, the relationship is much weaker, suggesting that movements among young adults have the strongest impact on population redistribution. For all age groups except those aged 18-24 years, the pattern over time resembles the pattern shown in Figure 6 for all ages. For young adults aged 18-24 years, the coefficients are strongly positive throughout the entire period. Migration among this age group redistributes population from rural to urban areas and thus clearly affects the spatial distribution of population. However, the impact has become slightly weaker with the end of the re-urbanisation phase around the year 2011. Focusing on the labour market entrants 
Fig. 6: Relationship between net internal migration rates and population density from 1991 to 2017 (b-coefficients and 95 percent confidence intervals)

b-coefficients

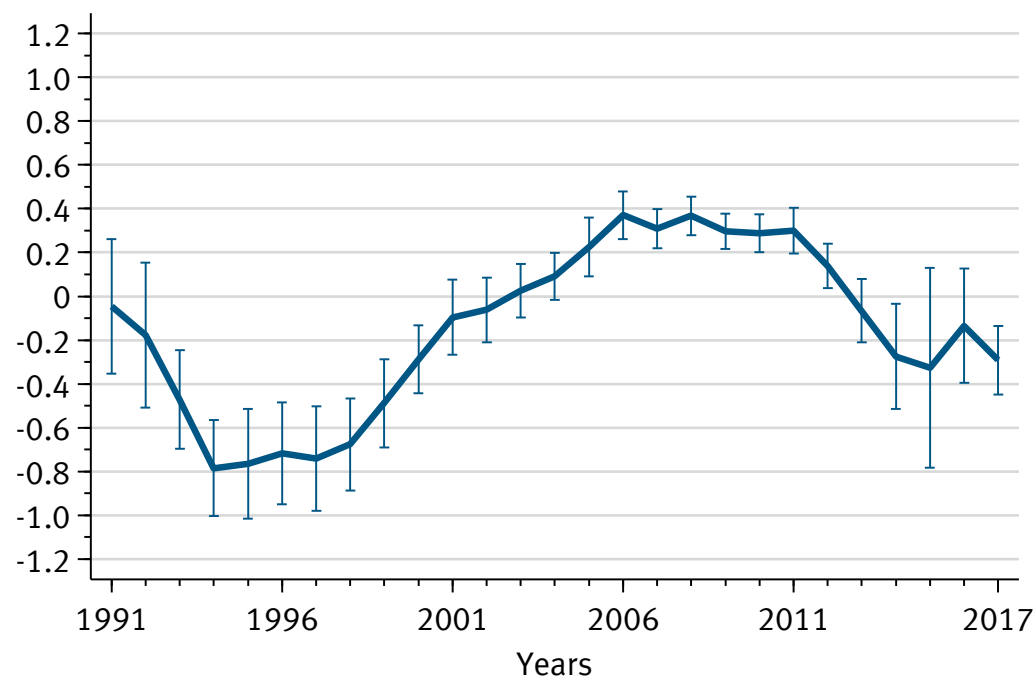

Source: Federal Statistical Office of Germany and the Statistical Offices of the Länder, Spatial Monitoring of the BBSR, own calculations

( 25 to 29 year olds, Fig. 7c), there is a weaker relationship between net migration rates and population density compared to the 18 to 24 year olds. This may be the result of jobs being more equally distributed across space compared to apprenticeships or universities. Families (under 18 and 30-49 year olds, Fig. 7a and d) usually show internal migration patterns towards lower density localities. Interestingly, in the re-urbanisation phase this relationship is weaker, indicating that families move more often to or stay in higher density areas. The relationship between internal migration and population density for those aged 50 and over is weakly negative (Fig. 7e and f). In sum, we find that the way in which internal migration alters the spatial distribution of population varies by age, with migration among younger adults towards densely populated areas having a stronger impact than movements among older adults to less densely populated regions.

In a next step, we determine the impact of internal migration on population redistribution relative to the impact of international migration and natural population change. Using net rates for all three components of change, we show their relationship with the log of population density for selected years deploying linear regression models (see Fig. 8). Years were selected to best capture the sub-urbanisation phase (in the 1990s), the transition phase from sub-urbanisation to re-urbanisation (early 2000s), the re-urbanisation phase (mid of the 2000s to the early 2010s), and the "new" sub-urbanisation phase (since the mid of the 2010s). The results show a nonlinear relationship with population density, especially for natural population 
Fig. 7: Relationship between net internal migration rates and population density from 1991 to 2017 for different age groups (b-coefficients and 95 percent confidence intervals)
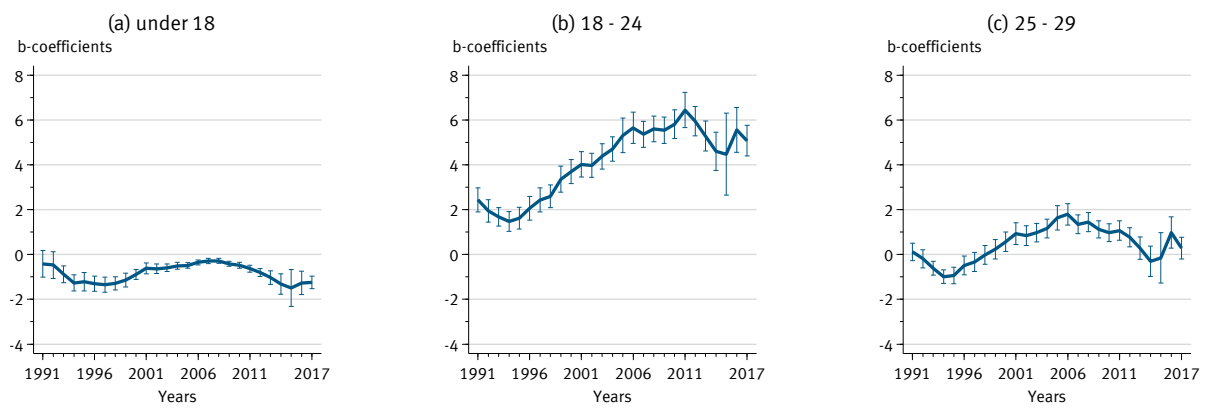

(d) $30-49$
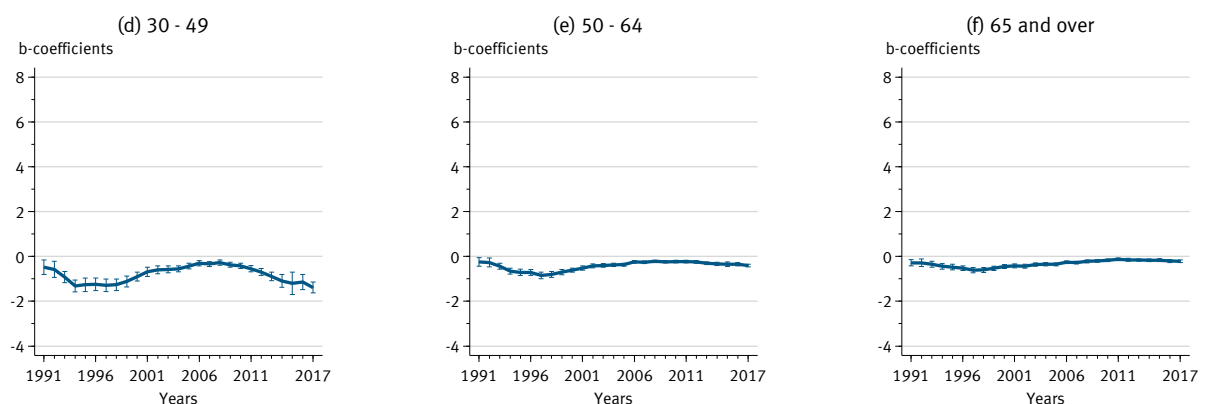

Source: Federal Statistical Office of Germany and the Statistical Offices of the Länder, Spatial Monitoring of the BBSR, own calculations

change. Given the nonlinearity, we calculate cubic relations between net rates and the log of population density. ${ }^{7}$

Our results show that in 1994, the relationship with international migration was positive across all regions, while the relationship with natural population change was negative (see Fig. 8a). For internal migration, the sub-urbanisation trend that time meant that the direction of the relationship varied strongly between low and highly dense regions. In 2003, the pattern for internal and international migration shifted, while the coefficients for natural population change were similar to those observed in 1994. For internal and international migration, we see that coefficients increase and change from negative to positive as population density rises. Regions with a density below 2.2 lose population, mainly as a result of negative net internal migration rates and negative natural population change, whereas populations increase in regions with a density above 2.2 due to positive migration rates overcompensating for negative natural population change. Figure 8c shows that in 2006 the impact of international migration was almost non-existent due to its very low

7 Note that we also checked nonlinear relations for all other analyses for which a linear relation is assumed and which lead to similar conclusions. 
Fig. 8: Net internal migration, natural population change and net international migration by population density

(a) 1994

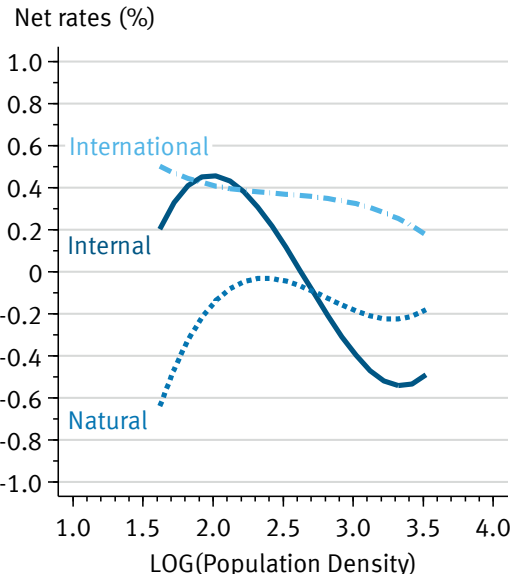

(c) 2006

Net rates (\%)

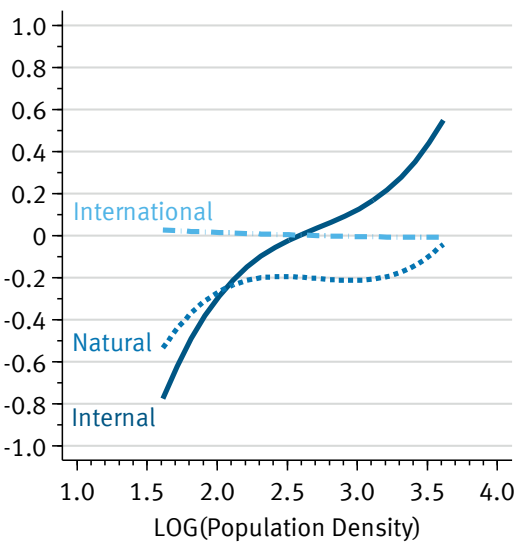

(b) 2003

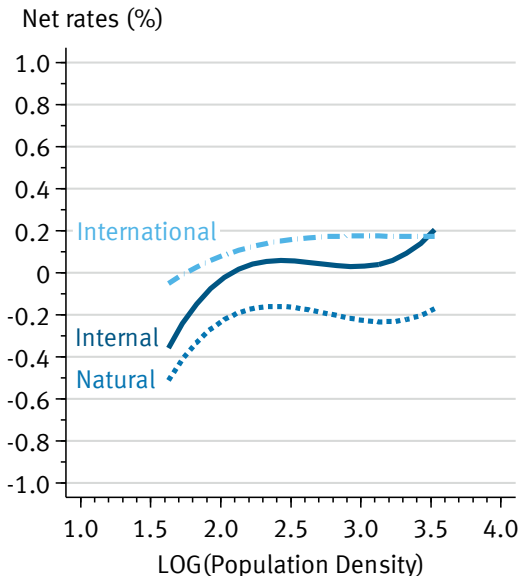

(d) 2017

Net rates $(\%)$

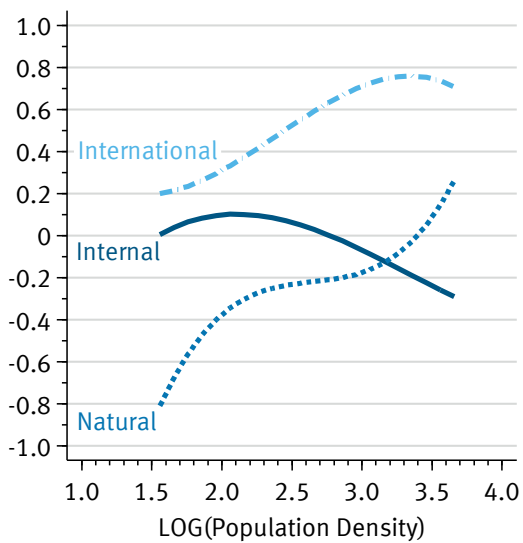

Source: Federal Statistical Office of Germany and the Statistical Offices of the Länder, Spatial Monitoring of the BBSR, own calculations

intensity, whereas the impact of internal migration became much more pronounced compared to previous years and caused a significant redistribution of population from less dense to more densely settled regions. In 2017, the pattern changed again with international migration causing population gains especially in highly dense areas (see Fig. 8d). The impact of natural population change has become more pronounced compared to previous years. The impact of internal migration has become weaker and coefficients are now negative for highly dense areas, confirming the beginning of a new phase of sub-urbanisation mentioned earlier. It is also worth 
noting that some highly dense regions gained population due to a positive natural population change in 2017 , somewhat counterbalancing the negative effect of internal migration for these regions.

In a final step, we determine the relationship between internal net migration rates, unemployment rates, GDP per capita, and rents for the years 2006 and 2017 (GDP was only available until 2016 at the time of writing). We use quadratic and cubic terms to visualise the relationship estimated by linear regression models. Figure 9 a shows that areas with an unemployment rate of 9 percent and above tend to experience negative net migration rates in 2006. This relation is weaker in 2017. However, if only German citizens are considered, the relationship is similar to that observed in 2006. Furthermore, while there was a positive relationship between GDP per capita and net migration in 2006, meaning the higher the GDP the higher the net gain, this relationship is reversed and weaker in 2016 (see Fig. 9b). This may be a result of the shift in internal migration patterns from re-urbanisation to suburbanisation. While in 2006 movements were directed towards high density areas with high GDP, in 2016 people were pushed out of the cities by soaring housing costs. Indeed, the relationship between rents and internal migration changed noticeably between 2006 and 2017. In 2006, the relationship was positive, indicating that regions with high rents recorded high net gains. In 2017, this relationship was negative (see Fig. 9c), suggesting that higher rents and limited housing availability in the cities were strongly associated with the shift in internal migration flows that we observed since 2011.

Fig. 9: Contextual factors influencing net internal migration
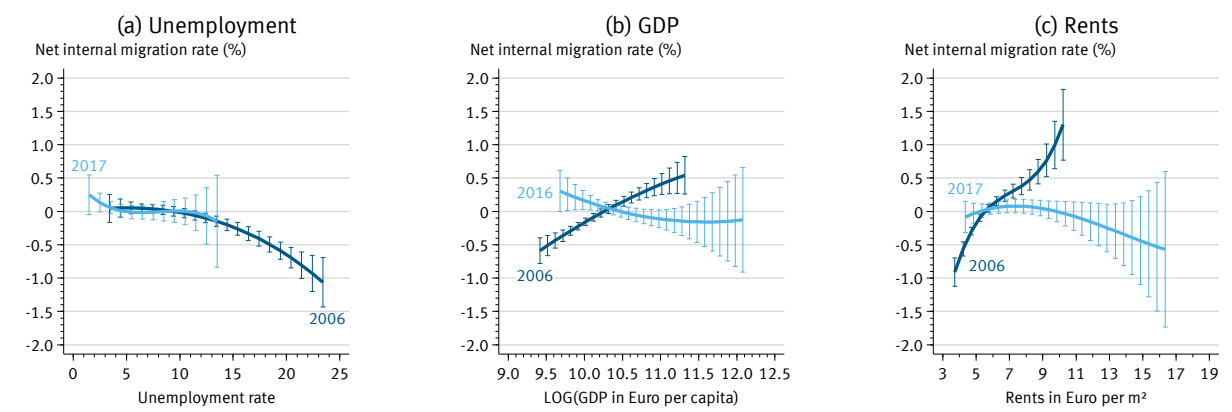

Source: Federal Statistical Office of Germany and the Statistical Offices of the Länder, Spatial Monitoring of the BBSR, own calculations

\section{$5 \quad$ Summary and Discussion}

This paper examined the impact of internal migration on the spatial distribution of population in Germany. We used a time-series dataset of inter-county migration flows in Germany for the period 1991 to 2017. Moreover, we employed the population density approach proposed by Rees and Kupiszewski (1999; see also Rees et al. 2017) to demonstrate that population density is a suitable proxy measure for settle- 
ment type, thus providing a valid alternative to the commonly used BBSR typology. Besides, the population density approach avoids the problem of continual changes in the settlement type classification.

The results show that around 3 percent of the population move across counties in Germany each year. While internal migration was modestly effective in redistributing population during the 1990s, its impact declined over time, presumably as a consequence of the decline in longer-distance migration from East to West Germany (e.g. Heiland 2004; Sander 2014). We have demonstrated that internal (and international) migration plays an important role in shaping the distribution of population across space. Even if internal migration flows are currently directed to less densely settled areas, our results show that it is not the remote rural areas that benefit from this trend, but the relatively densely populated areas within the greater regions around Munich, Frankfurt and Cologne.

Focusing on the distance moved we find that distances tended to be smaller during periods of sub-urbanisation and greater during periods of re-urbanisation. High volumes of East-West migration in the early 1990s and the early 2000s also seem to affect migration distances. This trend coincides with the shift in the relationship between internal net migration rates and population density over the same period. In the 2000s, the results show population gains due to internal migration in the highest density areas (re-urbanisation), this pattern switched back to sub-urbanisation and population gains for lower dense areas. Looking at age patterns, our results clearly show that young adults are the key driver of the re-urbanisation phase. Therefore, we find strong positive relations of population density and net internal migration rates of the 18 to 29 year olds. For all other age groups (under 18, 30 to 49,50 to 64 and 65 and over) the analysis shows a negative relation, which means that moves are directed to areas with lower densities. These age specific profiles of internal migration are in line with those found in previous work (e.g. Bernardi 2014; Milbert/ Sturm 2016). However, families and older adults also contribute to the shifts between sub- and re-urbanisation due to altered living preferences and the new attractiveness of the cities (e.g. Florida 2002; Storper/Scott 2009). Therefore, we find a reduced negative relation of population density and net internal migration rate for the period in which re-urbanisation takes place. Moreover, our results indicate that high rents and limited housing availability in the cities are key drivers of the recent shift from urbanisation to sub-urbanisation.

Of course, our study also has limitations. First, the analyses were done at the county level, and, as discussed earlier for the case of Berlin, this certainly biases our results due to the modifiable areal unit problem (MAUP). Therefore, similar analyses with smaller spatial units (e.g. at the municipality level) and with other spatial classifications are needed. Second, we did not consider covariates in the regression models, which is a fruitful avenue for future work. Third, since the macro-level data used here provide no information on the drivers of migration at the individual level, we used age as a proxy measure for the reason for moving. Therefore, data with more contextual information (e.g. the level of education) is needed to study internal migration in more detail. 
In summary, our study highlights - more than 120 years after Ravenstein (1885, 1889) published his two seminal papers - the importance of internal migration for shaping the population distribution in Germany. First, in line with the literature, we find that younger adults are more prone to migrate, and that their movements are a key driver of change in the age-distribution across space. This means that, on average, populations become younger in high density localities and older in regions with lower population density. Second, in line with Ravenstein, our results show a clear relationship between internal migration and economic wealth. However, this relationship is complex and varies over time. While internal migration in the 2000s seemed to be labour market oriented (i.e. a dominance of movements to places with high GDP per capita), the pattern in the 2010s became more motivated by other factors due to increased rents in the cities (i.e. a pattern of short-distance moves to places with lower GDP). Third, we find mixed results regarding the unidirectional trend towards urbanisation that Ravenstein noted. We find periods in which more rural areas gain population, while in other periods the same is true for cities. However, as the urban development model (Geyer/Kontuly 1993) proposes, we find that the change between sub-urbanisation and urbanisation also leads to stronger migration links between cities and their surroundings.

We conclude by identifying aspects in need of further research. The approach proposed by Plane and Jurjevich (2009) should be used in the German context to study migration flows up and down the urban hierarchy. Furthermore, given that our results suggest that densely settled regions exhibited positive natural population change in recent years, the impact of migration on regional fertility rates needs to be studied in more detail. Lastly, since internal migration changes the distribution of the population over space, but not all migrants change their place of work upon moving internally, further work should examine how internal migration affects commuting flows at the regional level.

\section{Acknowledgements}

We are grateful to Antonia Milbert for kindly providing the data on migration flows, population size and regional characteristics, and for the helpful comments of the editor and the anonymous reviewers in preparing the manuscript.

\section{References}

Adam, Brigitte; Driessen, Kathrin; Münter, Angelika 2008: Wie Städte dem Umland Paroli bieten können. Forschungsergebnisse zu Wanderungsmotiven, Standortentscheidungen und Mobilitätsverhalten. In: Raumforschung und Raumordnung 66,5: 398-414 [doi: 10.1007/BF03183184].

Amcoff, Jan 2006: Rural Population Growth in Sweden in the 1990s: Unexpected Reality or Spatial - Statistical Chimera? In: Population, Space and Place 12,3: 171-185 [doi: 10.1002/psp.407].

Anselin, Luc 2009: Spatial Regression. In: Fotheringham, A. Stewart; Rogerson, Peter A. (Eds.): The SAGE Handbook of Spatial Analysis. London: Sage: 255-275. 
Batty, Michae/ 1976: Urban Modelling: Algorithms, Calibrations, Predictions. London: Cambridge University Press.

BBSR (Bundesinstitut für Bau-, Stadt- und Raumforschung) 2018a: Immobilienpreisentwicklungen in Deutschland. 01/2018. BBSR-Berichte KOMPAKT. Bonn.

BBSR (Bundesinstitut für Bau-, Stadt- und Raumforschung) 2018b: Zuwanderung in die Städte. 09/2018 BBSR-Analysen KOMPAKT. Bonn.

BBSR (Bundesinstitut für Bau-, Stadt- und Raumforschung) 2016: Neue Ansichten auf die Wohnungsmieten. 08/2016 BBSR-Analysen KOMPAKT. Bonn.

BBSR (Bundesinstitut für Bau-, Stadt- und Raumforschung) 2010: Gebietsreformen politische Entscheidungen und Folgen für die Statistik. 6/2010. BBSR-Berichte KOMPAKT. Bonn.

Becker, Gary S. 1975: Human Capital. New York: National Bureau of Economic Research.

Bell, Martin et al. 2015: Internal Migration and Development: Comparing Migration Intensities Around the World. In: Population and Development Review 41,1: 33-58 [doi: 10.1111/j.1728-4457.2015.00025.x].

Bell, Martin et al. 2002: Cross-National Comparison of Internal Migration: Issues and Measures. In: Journal of the Royal Statistical Society: Series A 165,3: 435-464 [doi: 10.1111/1467-985X.t01-1-00247].

Bernard, Aude; Bell, Martin; Charles-Edwards, Elin 2014: Life-Course Transitions and the Age Profile of Internal Migration. In: Population and Development Review 40,2: 213-239 [doi: 10.1111/j.1728-4457.2014.00671.x].

Bernardi, Fabrizio 2014: Compensatory Advantage as a Mechanism of Educational Inequality: A Regression Discontinuity Based on Month of Birth. In: Sociology of Education 87,2: 74-88 [doi: 10.1177/0038040714524258].

Birg, Herwig 1974: Regionale Verteilung der Binnen- und Außenwanderungen in der Bundesrepublik Deutschland. In: DIW Wochenbericht 41,6: 41-50.

BMVI (Bundesministerium für Verkehr und digitale Infrastruktur) 2018: Regionalstatistische Raumtypologie (RegioStaR) des BMVI für die Mobilitäts- und Verkehrsforschung. Bonn.

Bocquier, Philippe 2005: World Urbanization Prospects: An Alternative to the UN Model of Projection Compatible with the Mobility Transition Theory. In: Demographic Research 12: 197-236 [doi: 10.4054/DemRes.2005.12.9].

Borjas, George J.; Bronars, Stephen G.; Trejo, Stephen J. 1992: Self-Selection and Internal Migration in the United States. In: Journal of Urban Economics 32,2: 159-185 [doi: 10.1016/0094-1190(92)90003-4].

Brenner, Neil; Schmid, Christian 2014: The "Urban Age" in Question. In: International Journal of Urban and Regional Research 38,3: 731-755 [doi: 10.1111/1468-2427.12115].

Buettner, Thomas 2015: Urban Estimates and Projections at the United Nations: The Strengths, Weaknesses, and Underpinnings of the World Urbanization Prospects. In: Spatial Demography 3,2: 91-108 [doi: 10.1007/s40980-015-0004-2].

Bujard, Martin 2011: Family Policy and Demographic Effects: The Case of Germany. In: Demográfia 54,5: 56-78.

Burda, Michael C.; Hunt, Jennifer 2001: From Reunification to Economic Integration: Productivity and the Labour Market in East Germany. In: Brooking Papers on Economic Activity 2: 1-92 [doi: 10.1353/eca.2001.0016]. 
Busch, Roland 2016: Inländische Wanderungen in Deutschland - wer gewinnt und wer verliert? In: Zeitschrift für Immobilienökonomie 2,2: 81-101 [doi: 10.1365/s41056-0160012-3].

Buzar, Stefan et al. 2007: Splintering Urban Populations: Emergent Landscapes of Reurbanisation in Four European Cities. In: Urban Studies 44,4: 651-677 [doi: 10.1080/00420980601185544].

Champion, Tony 2001: Urbanization, Suburbanization, Counterurbanization and Reurbanization. In: Paddison, Ronan (Ed.): Handbook of Urban Studies. London: Sage: 143161.

Clark, Terry Nichols et al. 2002: Amenities Drive Urban Growth. In: Journal of Urban Affairs 24,5: 493-515 [doi: 10.1111/1467-9906.00134].

Coombes, Mike; Raybold, Simon 2001: Public Policy and Population Distribution: Developing Appropriate Indicators of Settlement Patterns. In: Environment and Planning C: Government and Policy 19,2: 223-248 [doi: 10.1068/c9826].

Decressin, Jörg 1994: Internal Migration in West Germany and Implications for EastWest Salary Convergence. In: Review of World Economics 130,2: 231-257.

Dittrich-Wesbuer, Andrea; Föbker, Stefanie; Osterhage, Frank 2008: Demographic Change and Migration in City Regions: Results from Two German Case Studies. In: Zeitschrift Für Bevölkerungswissenschaft 33,3-4: 315-350 [doi: 10.1007/s12523-0090019-0].

Elder, Glen H. 1978: Family History and the Life Course. In: Hareven, Tamara K. (Ed.): Transitions - the Family and the Life Course in Historical Perspective. New York: Academic Press: 17-64.

Esser, Hartmut 1996: Soziologie. Allgemeine Grundlagen. Frankfurt/New York: Campus.

Florida, Richard 2017: The New Urban Crisis. Gentrification, Housing Bubbles, Growing Inequality, and What We Can Do About It. London: Oneworld.

Florida, Richard 2002: The Rise of the Creative Class. And How It's Transforming Work, Leisure, Community and Everyday Life. New York: Basic Books.

Frey, William H. 2017: City Growth Dips below Suburban Growth, Census Shows. In: Brookings 30.5.2017 [https://www.brookings.edu/blog/the-avenue/2017/05/30/citygrowth-dips-below-suburban-growth-census-shows/, 10.01.2019].

Fritsch, Michael; Stützer, Michael 2007: Die Geographie der Kreativen Klasse in Deutschland. In: Raumforschung und Raumordnung 65,1: 15-29 [doi: 10.1007/ BF03183820].

Gans, Paul 2017: Urban Population Development in Germany (2000-2014): The Contribution of Migration by Age and Citizenship to Reurbanisation. In: Comparative Population Studies 42: 319-352 [doi: 10.12765/CPoS-2018-01en].

Gatzweiler, Hans-Peter 1975: Zur Selektivität interregionaler Wanderungen. Bonn: Bundesforschungsanstalt für Landeskunde und Raumordnung.

Gatzweiler, Hans-Peter; Sch/ömer, Claus 2008: Zur Bedeutung von Wanderungen für die Raum- und Stadtentwicklung. In: Informationen zur Raumentwicklung 3/4: 245-259.

Geppert, Kurt; Gornig, Martin 2010: Mehr Jobs, mehr Menschen: die Anziehungskraft der großen Städte wächst. In: DIW Wochenbericht 77,19: 2-10.

Geppert, Kurt; Gornig, Martin; Werwatz, Axel 2008: Economic Growth of Agglomerations and Geographic Concentration of Industries - Evidence for West Germany. In: Regional Studies 42,3: 413-421 [doi: 10.1080/00343400701291518]. 
Geyer, Hermanus S.; Kontuly, Thomas 1993: A Theoretical Foundation for the Concept of Differential Urbanization. In: International Regional Science Review 15,2: 157-177 [doi: 10.1177/016001769301500202].

Green, Anne 2018: Understanding the Drivers of Internal Migration. In: Champion, Tony; Cooke, Thomas; Shuttleworth, lan (Eds.): Internal Migration in the Developed World. Are We Becoming Less Mobile? New York: Routledge: 31-55.

Greenwood, Michael J. 2014: Migration and Labor Market Opportunities. In: Fischer, Manfred M.; Nijkamp, Peter (Eds.): Handbook of Regional Science. Volume 1. Heidelberg: Springer: 3-16.

Greenwood, Michael J. 1975: Research on Internal Migration in the United States: A Survey. In: Journal of Economic Literature 13,2: 397-433.

Harris, John R.; Todaro, Michael P. 1970: Migration, Unemployment and Development: A Two-Sector Analysis. In: The American Economic Review 60,1: 126-142.

Haußmann, Michael 2007: Einwohnerentwicklung von 1995 bis 2005 in den 15 größten deutschen Städten und deren Umland. In: Statistik und Informationsmanagement 3/2007: 61-68.

Heiland, Frank 2004: Trends in East-West German Migration from 1989 to 2002. In: Demographic Research 11,7: 173-194 [doi: 10.4054/DemRes.2004.11.7].

Henger, Ralph; Oberst, Christian 2019: Immer mehr Menschen verlassen die Großstädte wegen Wohnungsknappheit. IW-Kurzbericht 20/2019. KöIn: Institut der deutschen Wirtschaft.

Herfert, Günter; Osterhage, Frank 2012: Wohnen in der Stadt: Gibt es eine Trendwende zur Reurbanisierung? Ein quantitativ-analytischer Ansatz. In: Brake, Klaus; Herfert, Günter (Eds.): Reurbanisierung. Materialität und Diskurs in Deutschland. Wiesbaden: Springer VS: 86-112 [doi: 10.1007/978-3-531-94211-7_6].

Huinink, Johannes 2005: Räumliche Mobiltiät und Familienentwicklung. Ein lebenslauftheoretischer Systematisierungsversuch. In: Steinbach, Anja (Ed.): Generatives Verhalten und Generationenbeziehungen. Wiesbaden: VS: 61-81.

Kawka, Rupert; Sturm, Gabriele 2006: Objektive regionale Lebensqualität und subjektives Wohlbefinden. Was macht Bürgerinnen und Bürger zufrieden? In: Informationen zur Raumentwicklung 6/7: 309-316.

Kecskes, Robert 1994: Abwanderung, Widerspruch, Passivität. Oder: Wer zieht wann um? In: Zeitschrift für Soziologie 23,2: 129-144 [doi: 10.1515/zfsoz-1994-0204].

Kemper, Franz-Josef 1985: Die Bedeutung des Lebenszyklus-Konzepts für die Analyse intraregionaler Wanderungen. In: Kemper, Franz-Josef; Laux, Hans-Dieter; Thieme, Günter (Eds.): Geographie als Sozialwissenschaft. Beiträge zu ausgewählten Problemen kulturgeographischer Forschung. Bonn: Ferd. Dümmler: 180-212.

Kontuly, Thomas et al. 1997: Political Unification and Regional Consequnences of German East-West Migration. In: International Journal of Population Geography 3,1: 31-47 [doi: 10.1002/(SICI)1099-1220(199703)3:1<31::AID-IJPG54>3.0.CO;2-G].

Kratz, Fabian; Brüderl, Josef 2013: Returns to Regional Migration: Causal Effect or Selection on Wage Growth? In: Schmollers Jahrbuch 133,2: 227-238 [doi: 10.3790/ schm.133.2.227].

Krugman, Paul 1991: Geography and Trade. Leuven: University Press.

Kühntopf, Stephan; Stedfeld, Susanne 2012: Wenige junge Frauen im ländlichen Raum: Ursachen und Folgen der selektiven Abwanderung in Ostdeutschland. BiB Working Paper 3/2012. Wiesbaden: Bundesinstitut für Bevölkerungswissenschaften. 
Lee, Everett S. 1966: A Theory of Migration. In: Demography 3,1: 47-57 [doi: $10.2307 / 2060063$

Lersch, Philip M. 2014: Residential Relocations and Their Consequences. Life Course Effects in England and Germany. Wiesbaden: Springer VS.

Mai, Ralf; Micheel, Frank 2008: Die regionale Bevölkerungsentwicklung in Deutschland seit 1990. In: Mai, Ralf; Micheel, Frank (Eds.): Der Einfluss des demographischen Wandels auf die föderalen Finanzstrukturen. Wiesbaden: Bundesinstitut für Bevölkerungswissenschaften: 15-52.

Mai, Ralf; Roloff, Juliane; Micheel, Frank 2007: Regionale Alterung in Deutschland unter besonderer Berücksichtigung der Binnenwanderungen. 120. Materialen zur Bevölkerungswissenschaft. Wiesbaden: Bundesinstitut für Bevölkerungswissenschaften.

Mayer, Karl Ulrich 2004: Whose Life? How History, Societies, and Institutions Define and Shape Life Courses. In: Research in Human Development 1,3: 161-187 [doi: 10.1207/ s15427617rhd0103_3].

Milbert, Antonia 2015: Raumabgrenzungen - Methodik und Entwicklung der BBSRTypen. In: Meinel, Gotthard et al. (Eds.): Flächennutzungsmonitoring VII. Boden Flachenmanagement - Analysen und Szenarien, IÖR Schriften 67. Berlin: RHOMBOS: 173-179.

Milbert, Antonia; Sturm, Gabriele 2016: Binnenwanderungen in Deutschland zwischen 1975 und 2013. In: Informationen zur Raumentwicklung 2: 121-144.

Mincer, Jacob 1978: Family Migration Decisions. In: Journal of Political Economy 86,5: 749-773 [doi: 10.1086/260710].

Mulder, Clara H. 1993: Migration Dynamics: A Life Course Approach. Amsterdam: Thesis Publishers.

Mulder, Clara H.; Hooimeijer, Pieter 1999: Residential Relocations in the Life Course. In: van Wissen, Leo J.G.; Dykstra, Pearl A. (Eds.): Population Issues. An Interdisciplinary Focus. New York: Kluwer Academic: 159-186.

OECD 2007: OECD Rural Policy Reviews: Germany. Paris: OECD.

Parr, John B. 2007: Spatial Definitions of the City: Four Perspectives. In: Urban Studies 44,2: 381-392 [doi: 10.1080/00420980601075059].

Plane, David A.; Jurjevich, Jason R. 2009: Ties That No Longer Bind? The Patterns and Repercussions of Age-Articulated Migration. In: The Professional Geographer 61,1: 4-20 [doi: 10.1080/00330120802577558].

Rabe-Hesketh, Sophia; Skrondal, Anders 2012: Multilevel and Longitudinal Modeling Using Stata. Volume I: Continuous Responses. Texas: Stata Press Publication.

Ravenstein, Ernest George 1889: The Laws of Migration. In: Journal of the Royal Statistical Society 52,2: 241-305 [doi: 10.2307/2979333].

Ravenstein, Ernest George 1885: The Laws of Migration. In: Journal of the Royal Statistical Society 48,2: 167-235 [doi: 10.2307/2979181].

Rees, Philip et al. 2017: The Impact of Internal Migration on Population Redistribution: An International Comparison. In: Population, Space and Place 23,6: 1-22 [doi: 10.1002/ psp.2036].

Rees, Philip; Kupiszewski, Marek 1999: Internal Migration and Regional Dynamics in Europe: A Synthesis. Strasbourg: Council of Europe.

Rossi, Peter H. 1980: Why Families Move. 2nd. ed. Beverly Hills: Sage. 
Sander, Nikola 2018: Germany. Internal Migration within a Changing Nation. In: Champion, Tony; Cooke, Thomas; Shuttleworth, Ian (Eds.): Internal Migration in the Developed World. Are We Becoming Less Mobile? New York: Routledge: 226-241.

Sander, Nikola 2014: Internal Migration in Germany, 1995-2010: New Insights into EastWest Migration and Re-Urbanisation. In: Comparative Population Studies 39,2: 217 246 [doi: 10.12765/CPoS-2014-04en].

Schlömer, Claus 2009: Binnenwanderungen in Deutschland zwischen Konsolidierung und neuen Paradigmen. 31. Bonn: BBSR \& BBR.

Schulz, Andrea 2009: Brain drain aus Ostdeutschland? Ausmaß, Bestimmungsgründe und Folgen selektiver Abwanderung. Leipzig: Deutsche Akademie für Landeskunde.

Shryock, Henry S.; Siegel, Jacob S. 1975: The Methods and Materials of Demography. Washington DC: US Bureau of the Census.

Siedentop, Stefan 2008: Die Rückkehr der Städte? Zur Plausibilität der Reurbanisierungshypothese. In: Informationen zur Raumentwicklung 3/4.2008: 193-207.

Sobotka, Tomáš 2008: The Rising Importance of Migrants for Childbearing in Europe. In: Demographic Research 19: 225-248 [doi: 10.4054/DemRes.2008.19.9].

Stark, Oded; Bloom, David E. 1985: The New Economics of Labor Migration. In: The American Economic Review 75,2: 173-178.

Statistisches Bundesamt; Wissenschaftszentrum Berlin für Sozialforschung (Eds.) 2018: Datenreport 2018. Ein Sozialbericht für die Bundesrepublik Deutschland. Bonn: Bundeszentrale für politische Bildung.

Stillwell, John; Thomas, Michae/ 2016: How Far Do Internal Migrants Really Move? Demonstrating a New Method for the Estimation of Intra-Zonal Distance. In: Regional Studies, Regional Science 3,1: 28-47 [doi: 10.1080/21681376.2015.1109473].

Storper, Michael; Scott, Allen J. 2009: Rethinking Human Capital, Creativity and Urban Growth. In: Journal of Economic Geography 9,2: 147-167 [doi: 10.1093/jeg/lbn052].

Szymańska, Daniela et al. 2009: Internal Migration in Germany in 1990 and 2005. In: Bulletin of Geography. Socio-Economic Series 12: 109-120 [doi: 10.2478/v10089-0090007-0].

van Diepen, Albertine M.L.; Mulder, Clara H. 2009: Distance to Family Members and Relocations of Older Adults. In: Journal of Housing and the Built Environment 24,1: 31-46 [doi: 10.1007/s10901-008-9130-0].

Wenau, Georg; Grigoriev, Pavel; Shkolnikov, Vladimir 2019: Socioeconomic Disparities in Life Expectancy Gains among Retired German Men, 1997-2016. In: Journal of Epidemiology and Community Health [doi: 10.1136/jech-2018-211742].

Dr. Nico Stawarz $(\bowtie)$, Dr. Nikola Sander. Federal Institute for Population Research (BiB). Wiesbaden, Germany. E-mail: nico.stawarz@bib.bund.de,nikola.sander@bib.bund.de URL: https://www.bib.bund.de/DE/Institut/Mitarbeiter/Stawarz/Stawarz.html https://www.bib.bund.de/DE/Institut/Mitarbeiter/Sander/Sander.html 


\section{Comparative Population Studies}

WWW.comparativepopulationstudies.de

ISSN: 1869-8980 (Print) - 1869-8999 (Internet)

\section{Published by}

Prof. Dr. Norbert F. Schneider

Federal Institute for Population Research D-65180 Wiesbaden / Germany

\section{(c) BY-SA}

2019

\section{Managing Editor \\ Prof. Philip Rees \\ Dr. Katrin Schiefer}

\section{Copy Editor}

Julia Luther

\section{Editorial Assistant}

Beatriz Feiler-Fuchs

Wiebke Hamann

\section{Layout \\ Beatriz Feiler-Fuchs \\ E-mail:cpos@bib.bund.de}

\section{Scientific Advisory Board}

Karsten Hank (Cologne)

Michaela Kreyenfeld (Berlin)

Marc Luy (Vienna)

Natalie Nitsche (Vienna)

Peter Preisendörfer (Mainz)

Zsolt Spéder (Budapest)

Rainer Wehrhahn (Kiel)

\section{Board of Reviewers}

Martin Abraham (Erlangen)

Laura Bernardi (Lausanne)

Hansjörg Bucher (Bonn)

Claudia Diehl (Konstanz)

Andreas Diekmann (Zurich)

Gabriele Doblhammer-Reiter (Rostock)

Jürgen Dorbritz (Wiesbaden)

Anette Eva Fasang (Berlin)

E.-Jürgen Flöthmann (Bielefeld)

Alexia Fürnkranz-Prskawetz (Vienna)

Beat Fux (Salzburg)

Joshua Goldstein (Berkeley)

Sonja Haug (Regensburg)

Hill Kulu (Liverpool)

Aart C. Liefbroer (The Hague)

Kurt Lüscher (Konstanz)

Emma Lundholm (Umeå)

Nadja Milewski (Rostock)

Dimiter Philipov (Vienna)

Roland Rau (Rostock)

Tomáš Sobotka (Vienna)

Jeroen Spijker (Barcelona)

Olivier Thévenon (Paris)

Helga de Valk (Brussels)

Heike Trappe (Rostock)

Michael Wagner (Cologne) 